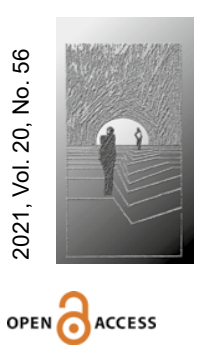

Hiroto Satō

http://orcid.org/0000-0002-4418-5778

Asahikawa University High School sato.hiroto@yahoo.com

Yuina Itō

http://orcid.org/0000-0002-3177-6149

Meijo University Senior High School

Yuina65@protonmail.com

DOI: $10.35765 / h w .2194$

\title{
Ignatian Pedagogy and Its Religious Inspirations
}

\begin{abstract}
RESEARCH OBJECTIVE: The aim of this article is to shed light on the religious inspirations that underpin Ignatian Pedagogy.
\end{abstract}

THE RESEARCH PROBLEM AND METHODS: The research problems involve questions concerning the most important ideas of Ignatian spirituality, which are based on the existential experience of St. Ignatius Loyola, and which are a source of inspiration for Ignatian Pedagogy. Based on the literature, the fundamental ideas of Ignatian Spirituality and their influence on the emergence and development of Ignatian Pedagogy were analysed.

THE PROCESS OF ARGUMENTATION: Starting from the historical stages of the formation of the key elements of Jesuit spirituality, the key moments of the spiritual experience of St Ignatius of Loyola are shown. The interpretation of the tenets of the Ignatian tradition and its spirituality made it possible to identify the vital ideas that constitute the sources of Ignatian Pedagogy.

RESEARCH RESULTS: The analysis leads to the conclusion that the modern concept of education should be built on the proper concept of the human being. One of the proposals is the concept of a person that we find in Ignatian Pedagogy. It is inspired by Ignatian Spirituality and describes humanity in the perspective of God's creative act and His love. In this context, the issues of individuality and freedom of each person are especially important.

CONCLUSIONS, INNOVATIONS AND RECOMMENDATIONS: Human existence in the changing and globalised world means a constant need to respond to change. Therefore, education should be understood as the familiarisation of students with change, which is a necessary condition for their development and thus for the progress of society. The Ignatian Pedagogy is effective in this regard, as it assumes an all-round development of a person and involves another person, an educator/mentor, who acts as a kind of witness to the ongoing history of life.

$\rightarrow$ KEYWORDS: IGNATIAN PEDAGOGY, SPIRITUAL EXERCISES, DISCERNMENT 


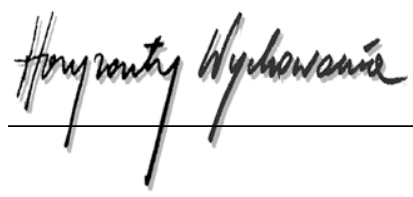

\section{STRESZCZENIE}

Pedagogika ignacjańska i jej religijne inspiracje

CEL NAUKOWY: Celem niniejszego artykułu jest ukazanie religijnych inspiracji, jakie legły u podstaw pedagogiki ignacjańskiej.

PROBLEM I METODY BADAWCZE: Problemami badawczymi były pytania dotyczące najważniejszych idei, które znajdują się w duchowości ignacjańskiej, bazującej na doświadczeniu egzystencjalnym św. Ignacego Loyoli, a które stanowią źródło inspiracji dla pedagogiki ignacjańskiej. Bazując na literaturze przedmiotu, analizowane był podstawowe idee duchowości ignacjańskiej i ich wpływ na powstanie i rozwój pedagogiki ignacjańskiej.

PROCES WYWODU: Wychodząc od historycznych etapów kształtowania się kluczowych elementów duchowości jezuickiej, ukazane zostały kluczowe momenty doświadczenia duchowego, jakie miał św. Ignacy z Loyoli. Interpretacja założeń tradycji ignacjańskiej i wiążącej się z nią duchowości umożliwiła wskazanie najważniejszych idei, które stanowią źródła pedagogiki ignacjańskiej.

WYNIKI ANALIZY NAUKOWEJ: Przeprowadzona analiza prowadzi do wniosku, że współczesna koncepcja edukacji powinna być budowana na właściwej koncepcji człowieka. Jedną z propozycji jest koncepcja człowieka, jaką odnajdujemy w pedagogice ignacjańskiej. Koncepcja ta inspiruje się duchowością ignacjańską i opisuje człowieka w perspektywie aktu stwórczego Boga i Jego miłości. W tym kontekście szczególnie istotne są kwestie dotyczące indywidualności i wolności każdej osoby.

WNIOSKI, INNOWACJE, REKOMENDACJE: Funkcjonowanie człowieka w zmieniającym się i zglobalizowanym świecie oznacza nieustanną konieczność do reagowania na zmiany. W związku z tym edukacja powinna być rozumiana jako oswajanie człowieka ze zmianą, co stanowi konieczny warunek jego rozwoju, a tym samym postępu społeczeństwa. Skuteczna w tym względzie jest pedagogika ignacjańska, która zakłada wszechstronny rozwój człowieka i stawia obok niego drugą osobę - wychowawcę/mentora pełniącego funkcję swego rodzaju świadka toczącej się historii życia.

$\rightarrow$ SŁOWA KLUCZOWE: PEDAgogiKa IgNACJAŃSKa, ĆWICZENIA DUchoWe, ROZEZNAWANIE

\section{Introduction}

St Ignatius did not include his pedagogical ideas in any book that could be considered an official synthesis of his view of the problem of education. Nor was he a writer or thinker by profession: he was first of all a man of reality, a man of action. His actions were profoundly thoughtful; he never took an important decision without thorough discernment. The outcomes of this insightful deliberation, prompted and partly motivated by the need for action, were contained in his three basic "works:" The Spiritual Exercises, the Constitutions of the Society of Jesus, and the many collections of letters and instructions written during his time as Superior General of the Order he founded. 
In general, it can be said that Ignatian Pedagogy is a vast collection of guidelines from the authorities of the Jesuit Order, publications and research by many authors with a distinctive educational approach, derived from the Jesuit Ratio studiorum ${ }^{1}$. It is a broad concept that offers a Christian vision of the world and of humankind, a humanistic direction of the educational process and an individual, critical and participatory method (Chubbuck, 2007, p. 248).

Ignatian pedagogy is not a method in the strict sense of the word, but a pedagogical approach whose main elements originate from the spirituality inspired by St. Ignatius of Loyola and involve, for example, the concept of the person, society, and God, as well as the ideal of life, the teaching/learning process and of working together with others (Giroux, 1988, p. 135).

For more than 30 years, Ignatian pedagogy has been distinguished from Jesuit pedagogy to emphasize that it refers to the vision of Ignatius of Loyola and can be practiced by people who are not affiliated with the Jesuit order. On the other hand, Jesuit pedagogy relates to the mission that the Society of Jesus undertakes in the field of education. The adjective "Ignatian" broadens the meaning of the term Jesuit pedagogy and also shifts the focus to a different area of activity. This adjective was probably first officially used in a speech given by the Superior General, Fr Pedro Arrupe, on 13 September 1980, when he addressed a group of Jesuit educational experts (Lindholm, 2008, p. 193).

The objective of the Ignatian Pedagogy is to help shape the human being through the process of education - formal and informal - in the recognition of his/her dignity, of his/her divine filiation and of his/her vocation to the "fullness" of life. Ignatian pedagogy aspires to stimulate people to develop their fullest potential and to act with autonomy in social transformation as well as in solidarity with others and with the surrounding world. This pedagogy attempts to educate conscious people who can apply the knowledge, competences and skills learned in school. These educated people are able to discern and find solutions to major social issues (Charchuła, 2020, p. 57). Furthermore, they are able to navigate the changing world and safeguard their lifelong education. The main purpose of this pedagogy is not to train people to climb the career ladder, but rather to develop an attitude of dialogue in order to serve others and society (Giroux, 2004, p. 146).

1 The Ratio Studiorum is a set of rules for the operation and administration of school education. In 1551 Ignatius Loyola instructed Fr. Nadal to write down the order of the school in force in Messina. The final draft was prepared by Fr Hannibal du Coudret. The Collegium Romanum became mater omnium scholarum founded by the Jesuits. In 1565 a draft Ratio studiorum was prepared (by Jacob Ledesma and other professors of the Roman College), but it was not accepted. Work began on a new version of the document, which was officially proclaimed in 1569 . The Ratio studiorum promulgated by the Order's General Francis Borgia was the first document organizing the functioning of schools at the level of the entire Society of Jesus. 


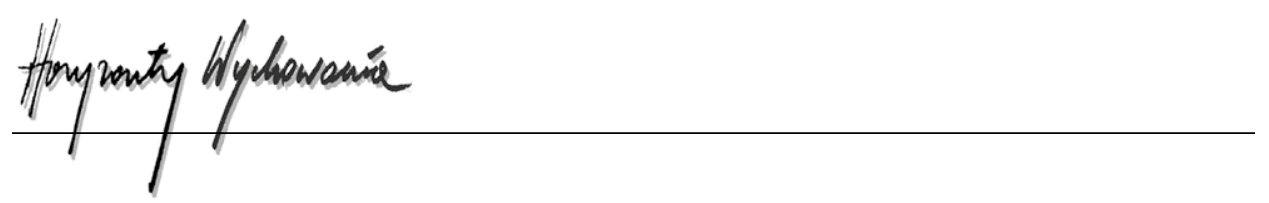

\section{Spiritual exercises}

One of the main sources of inspiration for Ignatian Pedagogy is the Spiritual Exercises of St Ignatius of Loyola. It is a modest book, which Pope Paul III legitimised as a road map that can benefit many people, including those who are not "the spiritual sons" of St Ignatius. It is especially worth highlighting those elements in the Spiritual Exercises that are relevant in the context of our theme of reflection. Firstly, the experience of the self-taught Ignatian, who, without a teacher to guide him in his discernment, learned to recognise and obey the inspirations coming from God, whom Ignatius called a teacher in his Autobiography. Secondly, a vital characteristic is the principle of "magis" in the pursuit of the goals set and commitments made. Ignatius demonstrated a persistent effort to investigate the origin, course and end of his inner motions and not to be satisfied with their superficial interpretation.

The Spiritual Exercises, often referred to as "retreats," are not, however, a theological treatise or a manual of devotion. Instead, they are a methodological guide for the instructor to help the disciple put his or her life in order, based on a personal, direct and profound experience of God's love. It is a path to liberation and integral development that anyone can take (Arrupe, 1981).

In analysing the Spiritual Exercises and Ignatian Pedagogy, it is worth noting the convergence of the two in the same goal. Just as the goal of the Exercises is not to train a pious man, so Ignatian Pedagogy does not claim to educate theoretically equipped academics. These two areas of activity aim to educate people of conviction and decision. Whereas in the Exercises, the search for truth through various manners of prayer is the priority, Ignatian Pedagogy pursues the same truth through various manners of study and research. As it is immersed in the Spiritual Exercises, Ignatian Pedagogy finds three essential elements from which it draws: a) the method; b) the understanding of relationships; c) the importance of integration.

\section{Method}

The method of the Spiritual Exercises has its roots mainly in the experiences and teachings of St Ignatius, especially in the Modus Parisiensis, which was developed in the 16th century at the University of Paris. The Spiritual Exercises are a method with a clear-cut aim, whose fruitfulness depends on God's grace, but also on conscious and generous work carried out on the path of a person's spiritual development. Since the objective is to reap the fruits of the exercises, one's motivation and determination are indispensable requirements for making progress. Each stage of the Spiritual Exercises has a goal and benchmarks for achieving it. The expression "manner and order" describes the formula that St. Ignatius, having experienced it himself, passes on to others who wish to apply it in achieving their goals. We could say that it is a technical dimension, which objectifies the inner experience of the person (International Commission on the Apostolate of Jesuit Education, 1993). 
An important element that constitutes a valuable basis for the pedagogy of the Spiritual Exercises is the principle of adapting its various elements to the circumstances of the exerciser. This procedure is flexible and progressive because it contextualizes the existential situation of the person by fitting the various exercises (prayer, reflection, etc.) to his or her time and place.

The spiritual exercises are thus a personalized pedagogical "action" in which each practitioner is treated as the most important person interested in his/her own development. The individual receives suggestions from the mentor, but it is up to the exerciser alone to make the effort to achieve the intended results (Johnson, 2002).

\section{Relationships}

The cornerstone of effective progress on the spiritual path is properly cultivated interpersonal relationships. In order to better understand them in the Spiritual Exercises, a person begins by recognising him or herself as a creature loved by God although abusing his or her freedom. In Ignatian Pedagogy, a person who is aware of his/her dignity, strengths and weaknesses can realise that the central place is not the teacher, the content or the methods, but himself/herself, with his/her history and background (Meissner, 1992, p. 85). The teacher/counsellor plays a crucial but unobtrusive role in this process. The role of the counsellor is demanding, as he/she works according to the principle of "talk less and think more" in order to best encourage the practitioner to achieve the desired result. The interpersonal relationship between the counsellor and the trainee translates into cura personalis, or the characteristic Jesuit way of working focused on the individuality of each person (O'Donnell, 1984, p. 469).

The experience of relationships is one of the most important fruits of the Spiritual Exercises. The mentee experiences the counsellor's suggestions as assistance which does not replace his or her personal work. The counsellor is a tutor and companion who, in a few words, suggests a path to be taken by the disciple. S/he must continue the work with courage and generosity, acting as a proper "guide" of his/her own discernment. The counsellor must not indoctrinate or impose anything, even if the mentee refuses to work on his or her own development.

\section{The vision of integration}

The third important inspiration that Ignatian Pedagogy draws from the Spiritual Exercises is an integrative vision of the person's four relationships: the relationship with oneself, with God, with others and with the environment. Through the Exercises, the person reflects - in different ways - both on the sin in his/her life and in the life of the world and on the mercy of God. They realize that God loves them with absolute benevolence, without any demands. The person is moved to see that God has never abandoned him or her 


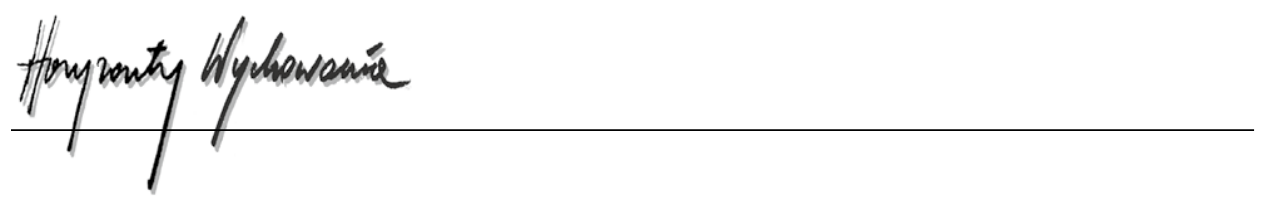

even in the most desperate moments, and loves him or her with a tender, compassionate and friendly love. Henceforth, the person will always remain a sinner but a sinner who has been forgiven as a result of God's "scandalous" mercy (Ivens, 1998, p. 84).

This experience of incommensurate love leads the person to a constant struggle, by discerning and rejecting "everything" that threatens or limits his or her freedom and thus prevents others from expressing their potential. In this context, it is necessary to ensure freedom, in particular, from negative self-conceptions and also from anti-values or harmful cultural injunctions (Massey, 2010, p. 462). It is also the freedom to dedicate one's life to the fulfilment of Christian values for the good and benefit of others.

Reconciled with himself and God, the human being will also seek to turn his or her eyes and heart away from distorted visions of God and relate to Him as a child, friend and partner in building the world. One begins to regard God not as estranged from this world, but manifest and acting here (Ivens, 1998, p. 139). The person realises that the glory of God is not worship or sacrifices but the human being him or herself, as the more integrated and fulfilled he or she is, the more he or she manifests the filiation of God. The integrative vision of the Spiritual Exercises helps to lift one out of individualism and indifference towards others (Oakes, 2013, p. 44).

From the above analyses, it is obvious that Ignatian pedagogy is an educational concept that is inspired by Ignatian spirituality, mostly expressed in the Spiritual Exercises. The anthropological, theological and cosmological concepts of the prolific body of Ignatian Pedagogy assert their own style in the world of education, without, however, claiming exclusivity. Ignatian Pedagogy seeks to personalise actions, since no one is born a person, but learns to be a person.

\section{Conclusions}

In order to respond to the challenges of the modern world, Ignatian Pedagogy seeks to remain faithful to the charism and spirituality of St. Ignatius of Loyola while remaining attentive to the signs of our times. St Ignatius found in Modus Parisiensis a method that marked the apostolic way of the Society of Jesus. The Spiritual Exercises remain relevant because they are practiced with a sensitivity to the uniqueness of each person and an openness to modern times.

Knowledge of the principles underlying Ignatian Pedagogy can help us today to remedy the problems of today's educational system. The conclusion that should follow from the Jesuit experience is that the educational process moulding the young generation should be based on the full truth about the human being. 


\section{BIBLIOGRAPHY}

Arrupe, P. (1981). Relevance of the society and its apostolate in the world of today. In: J. Aixala (ed.), Jesuit apostolates today (pp. 15-24). Anand Press.

Charchuła, J. (2020). Institutionalization of science and the social functions of the university - difficulties and opportunities. The Modern Higher Education Review, 5, 50-61.

Chubbuck, S. (2007). Socially just teaching and the complementarity of Ignatian pedagogy and critical pedagogy. Christian Higher Education, 6(3), 239-265.

Giroux, H.A. (1988). Teachers as intellectuals: Toward a critical pedagogy of learning. Bergin and Garvey.

Giroux, H.A. (2004). Critical pedagogy and the postmodern/modern divide: Towards a pedagogy of democratization. Teacher Education Quarterly, 31(1), 132-153.

International Commission on the Apostolate of Jesuit Education (ICAJE). (1993). Ignatian pedagogy: A practical approach. http://jesuitinstitute.org/Pages/lgnatianPedagogy.htm

Ivens, M. (1998). Understanding the Spiritual Exercises. Gracewing Publishing.

Johnson, W.B. (2002). The intentional mentor: Strategies and guidelines for the practice of mentoring. Professional Psychology: Research and Practice, 33(1), 78-90.

Lindholm, J.A. (2008). Spirituality and pedagogy: Faculty's spirituality and use of student-centered approaches to indergraduate teaching. Review of Higher Education, 31(2), 185-207.

Massey, D.W. (2010). Applying the Ignatian pedagogical paradigm to the creation of an accounting ethics course. Journal of Business Ethics, 96, 453-465.

Meissner, W. (1992). Ignatius of Loyola: The psychology of a saint. Yale University Press

Oakes, J. (2013). In Ignatian footsteps: Translational learning for educating and training adults in the 21st century. Jesuit Higher Education: A Journal, 2(2), 41-53.

O'Donnell, J.A. (1984). The Jesuit Ratio studiorum. Philippine Studies, 32(4), 462-475.

\section{Copyright and License}

This article is published under the terms of the Creative Commons Attribution - NoDerivs (CC BY- ND 4.0) License http://creativecommons.org/licenses/by-nd/4.0/ 